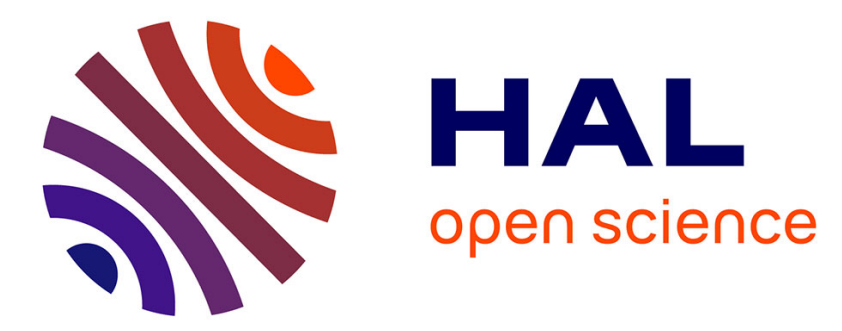

\title{
A 200-year climate record in Central Europe: implications for agriculture
}

Trnka, Brázdil, Dubrovský, Semerádová, Štěpánek, Dobrovolný, Možný, Eitzinger, Málek, Formayer, et al.

\section{- To cite this version:}

Trnka, Brázdil, Dubrovský, Semerádová, Štěpánek, et al.. A 200-year climate record in Central Europe: implications for agriculture. Agronomy for Sustainable Development, 2011, 31 (4), pp.631-641. 10.1007/s13593-011-0038-9 . hal-00930509

\section{HAL Id: hal-00930509 https://hal.science/hal-00930509}

Submitted on 1 Jan 2011

HAL is a multi-disciplinary open access archive for the deposit and dissemination of scientific research documents, whether they are published or not. The documents may come from teaching and research institutions in France or abroad, or from public or private research centers.
L'archive ouverte pluridisciplinaire HAL, est destinée au dépôt et à la diffusion de documents scientifiques de niveau recherche, publiés ou non, émanant des établissements d'enseignement et de recherche français ou étrangers, des laboratoires publics ou privés. 


\title{
A 200-year climate record in Central Europe: implications for agriculture
}

\author{
Miroslav Trnka • Rudolf Brázdil • Martin Dubrovský • Daniela Semerádová • \\ Petr Štěpánek • Petr Dobrovolný • Martin Možný • Josef Eitzinger • Jan Málek • \\ Herbert Formayer $\cdot$ Jan Balek $\cdot$ Zdeněk Žalud
}

Accepted: 7 February 2011 / Published online: 7 June 2011

(C) INRA and Springer Science+Business Media B.V. 2011

\begin{abstract}
The close links of climate, soil conditions, and agricultural productivity have been used in Central Europe for taxation purposes since the eighteenth century. Since agroclimatic conditions are variable, their fluctuations in the past centuries can provide a valuable context for analyzing changes expected in the coming decades. Here, historical agroclimatic conditions and future projections were constructed for key agricultural regions in Central Europe. The agroclimatic zoning method used in this study incorporates (1) the sum of temperatures for days with a mean temperature above $10^{\circ} \mathrm{C}$ during the frost-free period,
\end{abstract}

M. Trnka • D. Semerádová · J. Málek · J. Balek · Z. Žalud Institute of Agrosystems and Bioclimatology,

Mendel University in Brno,

Zemědělská 1 ,

61300 Brno, Czech Republic

M. Trnka $(\bowtie) \cdot$ D. Semerádová

CzechGlobe - Global Change Research Centre AS CR v.v.i., Poříčí $3 b$,

60300 Brno, Czech Republic

e-mail: mirek_trnka@yahoo.com

R. Brázdil • P. Dobrovolný

Institute of Geography, Masaryk University,

Brno, Czech Republic

M. Dubrovský

Institute of Atmospheric Physics, Czech Academy of Sciences, Prague, Czech Republic

P. Štěpánek • M. Možný

Czech Hydrometeorological Institute,

Prague, Czech Republic

J. Eitzinger $\cdot H$. Formayer

Institute of Meteorology,

University of Natural Resources and Applied Life Sciences,

Vienna, Austria
(2) the water deficit during the summer period from June to August, defined as the difference between precipitation and reference evapotranspiration, and (3) information regarding the suitability of soil and terrain for agriculture production based on twentieth century soil surveys. Changes in selected agroclimatological indices were also analyzed. To produce a weather series representing climate conditions between 1803 and 2008 over the study area, we used a stochastic weather generator trained on high-quality daily observations from 52 representative meteorological stations during the baseline period from 1961 to 1990 . To estimate the extent of agroclimatic zones and the values of selected agroclimatic indices, the parameters of the weather generator were perturbed by the deviations of the temperature and precipitation means from the baseline using a long-term climate series from 1803 to 2008, from Brno. To generate a weather series representing the climate in 2050 , we used an approach known as "pattern-scaling" in combination with outputs of three general circulation models. To our knowledge, this is the first study analyzing both continuous fluctuations in agroclimatic conditions over the past 200 years and expected shifts in the coming decades over Central Europe.

In the study region, our results demonstrate that changes in climate factors since the second half of the twentieth century have favored the expansion of warmer and drier agroclimatic conditions in the most fertile areas, progressively endangering the sustainability of rain-fed agriculture. Conversely, the agroclimatic conditions of regions at higher elevations have improved over the past six decades, as witnessed by increases in maize production areas but also an influx of previously absent pests, e.g., the European corn borer. The length of the vegetation summer has been increasing and shows daily average temperature exceeding $15^{\circ} \mathrm{C}$. The mean number of days with snow cover has decreased by up to 30 days since a peak in the late 
nineteenth century. In lowland areas, the date of the last frost, with a 20 -year return period, has moved closer to beginning of the season. Our results show that the predicted rate of change is unprecedented in available agroclimatic records; thus, adaptation cannot rely on past. Consequently, agricultural producers in the region will be forced to significantly bolster their adaptive capacity and develop flexible procedures that reflect the rapidly changing agroclimatic conditions.

Keywords Agroclimatic zoning - Climate reconstruction . Climate variability · Drought stress · Growing season

\section{Introduction}

The overall climatic conditions provide a general context for agriculture production and determine, to a large extent, the type of agricultural systems and growing conditions, including direct and indirect impacts on crop yield potentials, in a given region. Plant growth and development are related to environmental conditions through a combination of linear and nonlinear responses. Even processes for which the general response is linear are susceptible to conditions that can influence the rate of the process, e.g., the decreased speed of leaf expansion or the decreased rate of growth in most $\mathrm{C}_{3}$ crops when the air temperature is above a certain threshold (Porter and Gawith 1999). The influence of climatic factors extends beyond the conditions in a given year or season because the climate tends to exert a major influence on other indirect drivers related to crop yield potentials at the regional scale (e.g., weed and pest pressure, soil evolution and fertility, soil erosion, prevailing type of land-use or field size). However, because this influence occurs over decades, centuries or millennia (Klijn and de Haes 1994) and does not fit the standard time frame of traditional agricultural studies, it is typically neglected in analyses.

The close links among climate, soil conditions, and agricultural productivity have been used in Central Europe for taxation purposes since the eighteenth century (Korristka 1860; Němec 2001). Kořistka (1860) based his zoning on various agroclimatic indicators, including the length of the growing season, water availability, and the occurrence of late or early frosts, and his analysis was subjective and adhered to administrative borders. During this time period, farmers grouped fields into four major classes (16 total) based on the main cereals, wheat, barley, oat, and rye, for which a given field was the most suitable (Červený 1871). In the 1920s, more general zoning schemes covering a wider range of crops, including sugar beet and maize, were introduced; these delineations followed administrative rather than natural boundaries (Dokládal 1947). In the early 1970s, a new concept based on hydrothermal characteristics was applied in former Czechoslovakia (Petr 1991). The Czech Republic was divided into ten areas that provide similar climatic conditions for the production of field crops (Petr 1991; Němec 2001). In this scheme, five agroclimatic zones were defined and named after the most commonly grown crop in the region (Němec 2001). In the present study, the cereal- and potato-growing zones were merged into one category because of overlapping climate parameters (Table 1). The location of a region within a particular agroclimatic zone is a key indicator that determines the official land tax rate for farmers, characterizes the potential productivity of the land and determines the land's market value. A similar concept is used for taxation in Austria (Harlfinger and Knees 1999). While the number (four or

Table 1 Overview of thresholds used for agroclimatic zoning after Němec (2001)

\begin{tabular}{|c|c|c|c|c|c|c|c|c|}
\hline $\begin{array}{l}\text { Agroclimatic } \\
\text { zone }\end{array}$ & $\operatorname{TS} 10\left({ }^{\circ} \mathrm{C}\right)^{\mathrm{a}}$ & $\begin{array}{l}\mathrm{K}_{\mathrm{JJA}} \\
(\mathrm{mm})\end{array}$ & $\begin{array}{l}\text { Annual mean } \\
\text { air temperature } \\
\left({ }^{\circ} \mathrm{C}\right)\end{array}$ & $\begin{array}{l}\text { Annual } \\
\text { precipitation } \\
\text { total }(\mathrm{mm})\end{array}$ & $\begin{array}{l}\text { Prevailing } \\
\text { altitude } \\
\text { (m a.s.1.) }\end{array}$ & $\begin{array}{l}\text { Prevailing soils } \\
\text { (under present } \\
\text { climate) }\end{array}$ & $\begin{array}{l}\text { Major crops grown } \\
\text { in the zone }\end{array}$ & $\begin{array}{l}\text { Potential } \\
\text { productivity }(\%)^{\mathrm{c}}\end{array}$ \\
\hline $\begin{array}{l}\text { Grain } \\
\text { maize-growing }\end{array}$ & $2800-3200$ & -90 to -180 & $9-10$ & $450-600$ & $<250$ & $\begin{array}{l}\text { Chernozems, } \\
\text { fluvisols }\end{array}$ & $\begin{array}{l}\text { Grain maize, sugar beet, } \\
\text { grapes, peaches, apricots, } \\
\text { high-quality wheat, } \\
\text { malting barley }\end{array}$ & $>82$ \\
\hline Sugar beet-growing & $2550-2950$ & -50 to -120 & $8-9$ & $500-650$ & $250-350$ & $\begin{array}{l}\text { Chernozems, } \\
\text { cambisols }\end{array}$ & $\begin{array}{l}\text { Sugar beet, grain maize, } \\
\text { grapes, high-quality wheat, } \\
\text { malting barley, hops }\end{array}$ & $>84$ \\
\hline $\begin{array}{l}\text { Cereal- and } \\
\text { potato-growing }\end{array}$ & $2150-2700$ & -100 to +130 & $5-8.5$ & $550-900$ & $300-650$ & Cambisols & $\begin{array}{l}\text { Cereals, rape, technical crops } \\
\text { (growing sugar beet is } \\
\text { not profitable) }\end{array}$ & $>56$ \\
\hline $\begin{array}{r}\text { Forage and } \\
\text { grassland }\end{array}$ & $<2150$ & $>-10$ & $5-6$ & $>700$ & $>600$ & $\begin{array}{l}\text { Poor } \\
\text { cambisols, } \\
\text { gleysols }\end{array}$ & $\begin{array}{l}\text { Potatoes, rye, flax, hay, } \\
\text { forage crops }\end{array}$ & $>34$ \\
\hline
\end{tabular}

${ }^{\text {a }} \operatorname{TS} 10\left({ }^{\circ} \mathrm{C}\right)$ : sum of temperatures in days with mean daily temperature above $10^{\circ} \mathrm{C}$

${ }^{\mathrm{b}} \mathrm{K}_{\mathrm{JJA}}$ : the water deficit during the period from June to August

${ }^{\mathrm{c}}$ Productivity as defined by Němec (2001) with $100 \%$ being the largest economic return possible 
five) and names of the agroclimatic zones are similar for the classification systems used in the study region, the represented spatial patterns are markedly different (e.g., Kořistka 1860; Dokládal 1947; Němec 2001). Some of these differences stem from different methodologies and initial datasets, but they may also be caused by long-term climate variability.

Changing climate conditions over the past few decades have made the basic assumption of agroclimatic zoning, that agroclimatic conditions remain stable in long-term, untenable (Perarnaud et al. 2005). When climate trends are not reflected in updates of agroclimatic zoning, farmers and the environment may suffer negative consequences from the application of potentially biased adaptation measures. Although the risks of using climatically inappropriate fertilization schemes, crop rotations, or cultivars are well known, subtle shifts in agroclimatic zones have rendered many practices obsolete or unsustainable in areas where the same approach would have constituted "good practice" only one generation ago.

One of the aims of the present study was to develop an objective methodology, with scientific merit and policy relevance, that would enable regionalization of a given study area based on the agroclimatic conditions under past, present and future climate conditions. The proposed methodology was used to assess the degree of variability of agroclimatic conditions in the study region over the past two centuries using nine 25 -year periods. The method enabled the reconstruction of past agroclimatic conditions by combining data from a dense network of recently installed climatological stations with global climate data. In addition, the same method can be used to project the extent of agroclimatic zones and thereby compare past changes with those expected during the next few decades.

\section{Methods}

\subsection{Description of the study area}

The study area is located in eastern Central Europe in southeast Czech Republic and northeast Austria between $46^{\circ} 34^{\prime}-50^{\circ} 10^{\prime} \mathrm{N}$ and $11^{\circ} 18^{\prime}-20^{\circ} 13^{\prime} \mathrm{E}$ (Fig. 1). It covers $69,163 \mathrm{~km}^{2}$ of land, 37,205 and $23,115 \mathrm{~km}^{2}$ of which are agricultural and arable lands, respectively. The area includes a wide range of agroclimatic conditions, from the

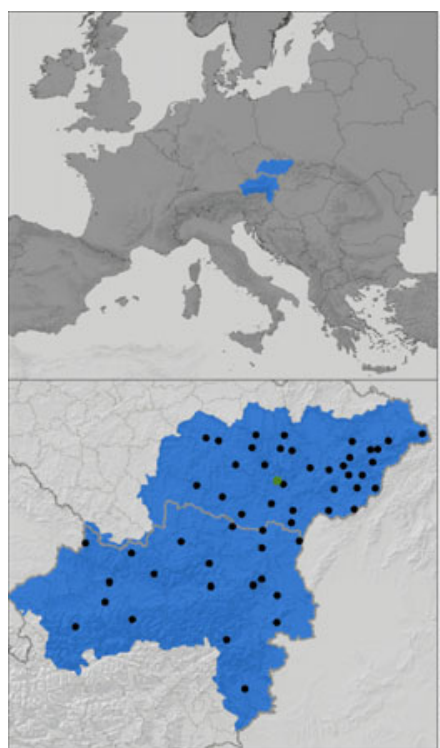

Legend

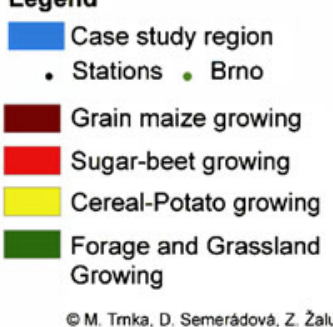

Case study region

- Stations - Brno

Grain maize growing

Sugar-beet growing

Cereal-Potato growing

Growing

OM. Tmka, D. Semeradova, Z. Żalud

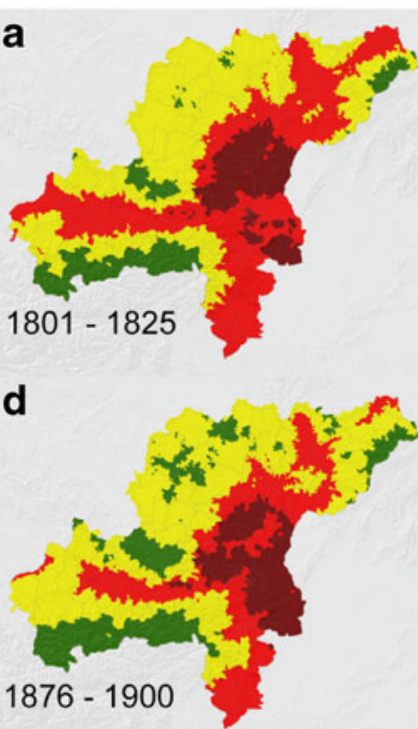

g

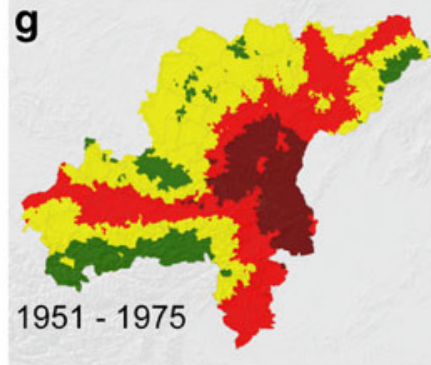

Fig. 1 Study area, climatological stations (left) and reconstructed agroclimatic zones for nine periods between 1803 and 2008 (a-i), using the thresholds listed in Table 1 and with regionalization of
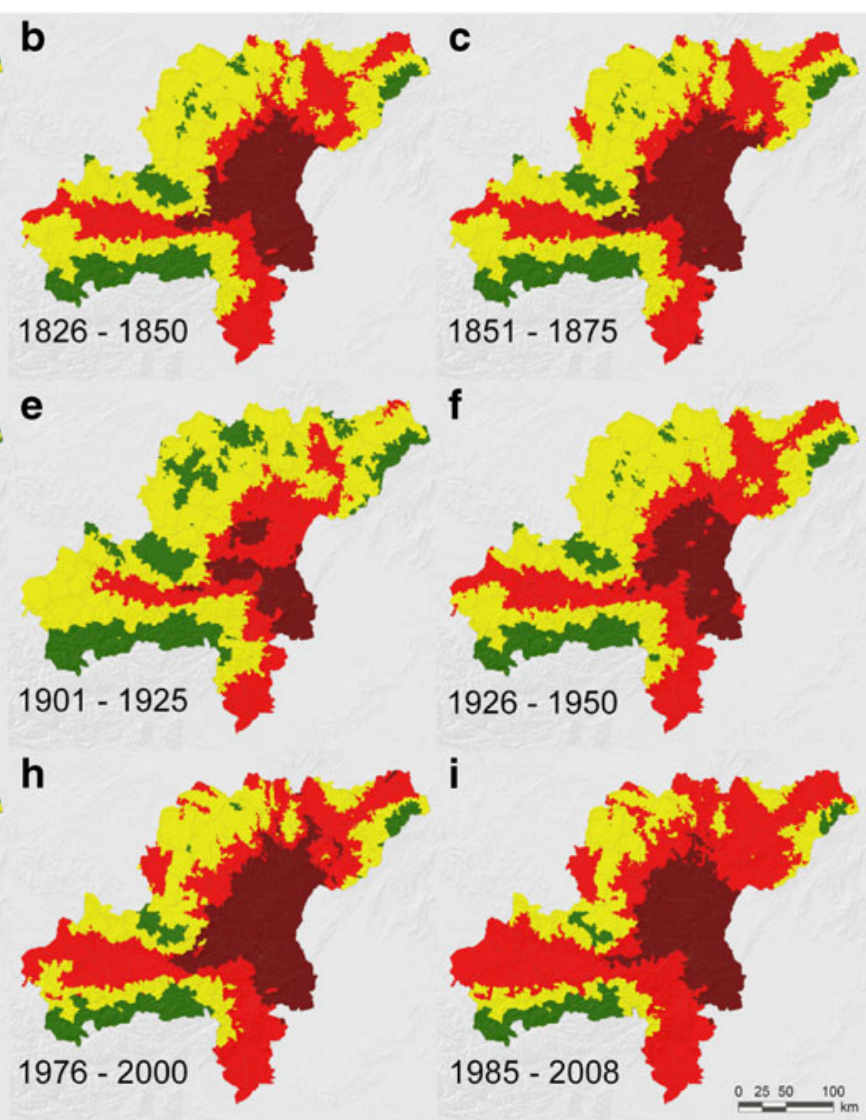

cadastre units. Grain maize- and sugar beet-growing zones tended to expand at the expense of forage and grassland zone 
relatively dry Pannonian Lowland to the comparatively wet highland and mountain regions including the northern-most fringe of Alps. Winter wheat, spring barley, and winter rape dominated production in the Czech Republic, and durum wheat, grain maize, soybeans, and sunflowers were dominant in the warmest parts of Austria. Grasslands prevailed in the highland and mountainous regions in both countries and were found, in particular, at the fringes of the study area. The baseline (1961-1990) climate conditions of the area were obtained from 52 climatological stations, and these data passed quality and homogeneity tests using ProClimDB and AnClim software (Štěpánek et al. 2009). The soil conditions were based on a 1:1,000,000 FAO map of soil types (BMLFW 2007) and complemented by a 1:500,000 soil map of the Czech Republic (Tomášek 2000) and a 1:25,000 soil map of Austria (Murer et al. 2004). The terrain was represented by a digital elevation model derived from the Shuttle Radar Topography Mission (Farr et al. 2007). Study results were interpolated to a $0.5 \times 0.5 \mathrm{~km}$ grid and aggregated into cadastre units.

\subsection{Reconstruction of regional climates for the period} from 1803 to 2008

For most of the twentieth century, observed weather data could be potentially used. However, the density of available data rapidly decreased prior to 1890 . To produce a weather series representing past climate conditions for the study area, we applied an approach routinely used in climate change studies (e. g., Trnka et al. 2004). This method is based on the use of the
Met\&Roll stochastic weather generator (Dubrovský et al. 2004), which was trained on daily observations from 52 meteorological stations during a baseline period from 1961 to 1990. During this procedure, statistical parameters of the weather generator that captured the properties of observed weather series were obtained for each site. The trained weather generator was then used to produce time series of weather data of an arbitrary length that climatologically resembled the observed series. When the statistical parameters are altered, for example, by modifying monthly temperature means or precipitation totals, series representing different climate conditions are produced. In this study, the weather generator was first perturbed by the deviations of the temperature and precipitation means representing predefined 25-year time periods from the past 200 years (Table 2). To determine the range of values by which the weather generator parameters were perturbed, continuous observations from Brno were used. Temperature measurements, beginning in May 1799, were provided by a pensioned captain, Ferdinand Knittelmayer (Brázdil et al. 2006). Continuous precipitation records, beginning in January 1803, were available from a land accountant, Zachariáš Melzer (Brázdil et al. 2005). These observations, available for more than two centuries in different parts of Brno without significant interruption, facilitated the compilation of qualitatively checked long-term monthly temperature and precipitation series. These series were homogenized in the framework of the HISTALP database to the recent position of the Brno airport station $\left(49^{\circ} 09^{\prime} \mathrm{N}, 16^{\circ}\right.$ $42^{\prime} \mathrm{E}, 241 \mathrm{~m}$ a.s.l.), where measurements were available starting in 1958 (Auer et al. 2005). The Brno temperature

Table $2 \mathrm{CO}_{2}$ concentration and changes in mean monthly temperatures and precipitation totals as key inputs for the development of daily data series using the pattern-scaling technique

\begin{tabular}{|c|c|c|c|c|c|c|c|c|c|}
\hline \multirow[t]{2}{*}{ Period } & \multirow{2}{*}{$\begin{array}{l}\text { Mean temperature } \\
\text { April-September } \\
\left({ }^{\circ} \mathrm{C}\right)^{\mathrm{a}}\end{array}$} & \multirow{2}{*}{$\begin{array}{l}\text { Mean precipitation } \\
\text { total June-August } \\
(\mathrm{mm})^{\mathrm{a}}\end{array}$} & \multirow{2}{*}{$\begin{array}{l}\text { TS10 } \\
\left({ }^{\circ} \mathrm{C}\right)^{\mathrm{b}}\end{array}$} & \multirow{2}{*}{$\begin{array}{l}\mathrm{K}_{\mathrm{JJA}} \\
(\mathrm{mm})^{\mathrm{c}}\end{array}$} & \multirow{2}{*}{$\begin{array}{l}\text { Mean } \mathrm{CO}_{2} \\
\text { concentration } \\
(\mathrm{ppmv})^{\mathrm{d}}\end{array}$} & \multicolumn{4}{|c|}{ Area within the given agroclimatic zone (\%) } \\
\hline & & & & & & $\begin{array}{l}\text { Grain } \\
\text { maize-growing }\end{array}$ & $\begin{array}{l}\text { Sugar } \\
\text { beet-growing }\end{array}$ & $\begin{array}{l}\text { Cereal- and } \\
\text { potato-growing }\end{array}$ & $\begin{array}{l}\text { Forage and } \\
\text { grassland }\end{array}$ \\
\hline $1803-1825$ & 15.1 & 223 & 2774 & -4 & 283 & 15.2 & 43.1 & 39.9 & 1.8 \\
\hline $1826-1850$ & 14.9 & 200 & 2722 & -32 & 285 & 24.3 & 32.2 & 40.4 & 3.1 \\
\hline $1851-1875$ & 14.8 & 186 & 2721 & -49 & 289 & 26.4 & 31.1 & 40.0 & 2.5 \\
\hline $1876-1900$ & 14.8 & 227 & 2635 & -2 & 292 & 16.4 & 28.2 & 49.1 & 6.3 \\
\hline $1901-1925$ & 14.5 & 225 & 2593 & 7 & 300 & 11.8 & 27.8 & 52.0 & 8.4 \\
\hline 1926-1950 & 15.2 & 221 & 2746 & -6 & 307 & 17.9 & 38.2 & 41.5 & 2.4 \\
\hline 1951-1975 & 15.0 & 222 & 2733 & -5 & 320 & 17.9 & 37.4 & 41.6 & 3.1 \\
\hline 1976-2000 & 15.5 & 184 & 2854 & -64 & 346 & 29.3 & 42.1 & 27.3 & 1.3 \\
\hline 1985-2008 & 16.2 & 196 & 3011 & -47 & 365 & 24.0 & 56.5 & 18.9 & 0.6 \\
\hline
\end{tabular}

The temperature and precipitation changes were with respect to 1975

${ }^{a}$ Mean temperatures from April to September and mean precipitation totals from June to August were derived from observations made at the Brno station (1803-2008)

${ }^{\mathrm{b}}$ Sum of temperatures during days with mean daily temperature above $10^{\circ} \mathrm{C}$ averaged over all 52 stations included in the study (Fig. 1)

${ }^{\mathrm{c}} \mathrm{K}_{\mathrm{JJA}}$ : the water deficit during the period from June to August

${ }^{\mathrm{d}}$ Carbon dioxide levels for historical periods were based on data provided in MAGICC v. 4.1 model 
series was representative of the entire studied region based on the spatially consistent temperature patterns in Central Europe (Dobrovolný et al. 2010). Although spatial precipitation correlations were slightly weaker than those for temperature, Brno was the only representative series available over an extended period in the study area.

\subsection{Regional climate change scenarios}

One approach used in this study to downscale the lowresolution output from General Circulation Model (GCM) into the spatial and temporal scales required for agroclimatic analysis involves the use of a stochastic weather generator, the parameters of which are calibrated using sitespecific weather observations and modified according to GCM-based climate change scenarios. This approach is widely used because of the flexibility of weather generators and the assumption that GCMs reproduce shifts in climatic characteristics more accurately than they reproduce absolute values of individual weather variables.

To produce weather series representing climate change, we used an approach known as "pattern-scaling" (Santer et al. 1990), in which the climate change scenario is defined by the product of a standardized scenario and the change in global mean temperature (Table 3). First, a set of three standardized scenarios that relate responses of climatic characteristics to a $1{ }^{\circ} \mathrm{C}$ rise in global mean temperature $\left(\Delta T_{\mathrm{G}}\right)$ were determined using a regression method and three GCMs. These GCMs included ECHAM5/MPI-OM, HadCM3, and NCAR-PCM, denoted as ECHAM, HadCM, and NCAR, respectively, in this article. Changes in $\Delta T_{\mathrm{G}}$ for the year 2050 were calculated with a simple climate model, MAGICC (Hulme et al. 2000), assuming the SRES-A2 emission scenario and high climate sensitivity (i.e., an equilibrium change in the global mean surface temperature of $4.5^{\circ} \mathrm{C}$ following a doubling of the atmospheric equivalent $\mathrm{CO}_{2}$ concentration, $\left.\Delta T_{\mathrm{G}, 2 \times \mathrm{CO} 2}\right)$. Then, daily weather series were prepared with a stochastic weather generator and the perturbations listed in Table 3. This approach is virtually the same as the procedure described in section 2.2 for the 1803-2008 period (the difference is that the GCMbased climate change scenarios are now used instead of the climate shifts based on historical observations). Ninetynine-year simulation runs were performed for all GCMs.

\subsection{Agroclimatic zoning and selected agroclimatic indicators}

The agroclimatic zoning method used in this study included the following main agroclimatic indicators: (1) temperature sums of all days with a mean temperature above $10^{\circ} \mathrm{C}$ during the frost-free period of the given year (TS10); (2) the water deficit during the period from June to August $\left(\mathrm{K}_{\mathrm{JJA}}\right)$, calculated as a difference between precipitation and reference evapotranspiration; and (3) information regarding the soil type and slope of the agricultural land. TS10 is a good proxy of growing season duration, and $\mathrm{K}_{\mathrm{JJA}}$ provides an integrated overview of precipitation and reference evapotranspiration during the summer, the season with the highest water demand. Reference evapotranspiration was

Table 3 Assumed change $(\Delta)$ in mean monthly temperature $\left(T_{\text {avg }}\right)$, precipitation total and global radiation, under the SRES-A2 emission scenario and high climate sensitivity (increase of global mean temperature by $4.5^{\circ} \mathrm{C}$ following a doubling of the $\mathrm{CO}_{2}$ concentration) in 2050

\begin{tabular}{|c|c|c|c|c|c|c|c|c|c|}
\hline \multirow[t]{2}{*}{ Month } & \multicolumn{3}{|c|}{$\Delta T_{\text {avg }}\left({ }^{\circ} \mathrm{C}\right)$} & \multicolumn{3}{|c|}{$\Delta$ Precipitation $(\%)$} & \multicolumn{3}{|c|}{$\Delta$ Global radiation $(\%)$} \\
\hline & HadCM & ECHAM & NCAR & HadCM & ECHAM & NCAR & HadCM & ECHAM & NCAR \\
\hline Jan & 2.5 & 3.3 & 2.3 & 16.0 & 30.8 & 20.1 & -8.2 & -3.3 & -9.8 \\
\hline Feb & 2.7 & 2.7 & 2.7 & 8.0 & 9.4 & 14.8 & -6.8 & -1.6 & -7.8 \\
\hline Mar & 2.3 & 2.5 & 1.4 & 3.1 & -9.8 & 25.8 & 0.4 & 1.2 & -6.8 \\
\hline Apr & 2.5 & 2.1 & 1.2 & 10.7 & -8.8 & 10.9 & 3.1 & 5.5 & 0.2 \\
\hline May & 2.7 & 1.4 & 1.4 & 5.5 & 17.0 & -3.3 & 4.7 & -2.5 & -0.4 \\
\hline June & 2.9 & 1.8 & 1.6 & -13.7 & -13.9 & -4.5 & 7.4 & 3.7 & 1.8 \\
\hline July & 3.9 & 2.7 & 2.9 & -28.7 & -24.8 & -9.6 & 7.0 & 5.9 & 8.6 \\
\hline Aug & 4.7 & 3.3 & 3.1 & -35.7 & -27.3 & -5.3 & 12.3 & 8.0 & 5.9 \\
\hline Sep & 4.3 & 2.7 & 2.5 & -20.3 & -23.2 & -18.5 & 13.5 & 5.1 & 8.2 \\
\hline Oct & 2.9 & 2.9 & 3.1 & 2.9 & 3.1 & -42.6 & 4.1 & 3.5 & 14.6 \\
\hline Nov & 2.3 & 2.5 & 2.9 & -5.7 & 13.5 & -8.6 & -1.0 & -1.4 & 2.7 \\
\hline Dec & 2.9 & 2.9 & 2.3 & 12.7 & 14.8 & 14.1 & -7.8 & -1.6 & -7.8 \\
\hline Year & 3.1 & 2.5 & 2.3 & -5.3 & -1.6 & -2.1 & 5.1 & 3.3 & 2.7 \\
\hline
\end{tabular}

The $\mathrm{CO}_{2}$ concentration in the target year was set to $535.9 \mathrm{ppm}$, and the corresponding change in global mean temperature was $2.05^{\circ} \mathrm{C}$. The values were based on the MAGICC v.4.1 model, and the temperature changes were with respect to 1975. HadCM, ECHAM, and NCAR were the General Circulation Models used in this study 
calculated at a daily time step using the Penman-Monteith equation (Allen et al. 2005), with adjustments (Table 2) for changing $\mathrm{CO}_{2}$ concentrations (Kruijt et al. 2008).

Based on the daily inputs, seasonal values of TS10 and $\mathrm{K}_{\mathrm{JJA}}$ were determined for each year of the period. The median values of both indices were calculated at each site and then interpolated using a geographically weighted regression method that accounted for the influence of altitude (Fotheringham et al. 2002). The interpolation errors of both parameters were similar for all periods and should not influence the overall results of the study. However, a substantial improvement in the resolution of climatic data is needed to ensure interpolation accuracy at the local level.

To verify the performance of the method described in section 2.2, all calculations for the 1985-2008 period were performed with observed data as well. The values of TS10 and $\mathrm{K}_{\mathrm{JJA}}$ at 52 climatological stations and those interpolated to individual cadastre units were not significantly different, and they agreed in more than $96 \%$ of cases. Similarly, the maps of agroclimatic conditions were nearly identical, with less than $3 \%$ of cadastre units classified differently in the two datasets.

Because climate alone does not guarantee profitable growing conditions in a region, additional abiotic factors must be considered. Therefore, soils, based on national soil survey data from 1961 to 1970 , were divided into the following three subclasses: (1) excellent and good soils that were extensively used for agriculture without serious limitations caused by soil properties (in Central Europe, these soils included chernozems, gray soils and fluvisols, with a water-holding capacity in the rooting zone that varied between soil polygons and was generally greater than $200 \mathrm{~mm}$ ); (2) fair quality soils with typical retention capacities between 140 and $220 \mathrm{~mm}$ and medium production capacities with some limitations, which, in many cases, were partly ameliorated by additional measures, such as drainage (in Central Europe, these soils included vertisols, eutric cambisols, and cambisols, with a $\mathrm{pH}>5.5$ ); and (3) soils of inferior quality. The accessibility of agricultural land to machinery was the final parameter used in the classification scheme. In this study, the domain was divided between areas with slopes of less and/or greater than $7^{\circ}$.

To provide additional information for the agroclimatological analysis of the past two centuries, the following four agroclimatological indices were considered: (1) the mean duration of the vegetation summer (i.e., the period with a mean daily air temperature continuously above $15^{\circ} \mathrm{C}$ ); (2) the number of days in the fifth percentile, with water stress between April and June (i.e., a 20-year drought); (3) the mean number of days with snow cover, calculated using the SnowMAUS model (Trnka et al. 2010); and (4) the date of the last spring frost, with a 20 -year return period. The values were listed for the following three locations: Schwechat $\left(48^{\circ} 6^{\prime} \mathrm{N}, 16^{\circ} 30^{\prime} \mathrm{E}, 184 \mathrm{~m}\right.$ a.s.l.), Kroměříž $\left(49^{\circ} 17^{\prime} \mathrm{N}, 17^{\circ} 24^{\prime} \mathrm{E}, 235 \mathrm{~m}\right.$ a.s.1.), and Bystřice nad Pernštejnem $\left(49^{\circ} 31^{\prime} \mathrm{N}, 16^{\circ} 15^{\prime} \mathrm{E}, 573 \mathrm{~m}\right.$ a.s.l.). These locations were representative of conditions for the three most prevalent agroclimatic zones (grain maize-growing, sugar beet-growing, and cereal and potato-growing).

\section{Results and discussion}

Compared to all analyzed periods, the first quarter of the twentieth century was the coldest and wettest. For the period from April to September, the mean temperature was $0.6^{\circ} \mathrm{C}$ below the mean temperature of the $1803-1825$ period and $1.7^{\circ} \mathrm{C}$ below the mean of the $1985-2008$ period (Table 2). Regarding summer precipitation or TS10 (Table 2), the temporal patterns were less pronounced, and the highest summer water deficits $\mathrm{K}_{\mathrm{JJA}}$ were calculated for the 1851-1875, 1976-2000, and 1985-2008 periods.

Table 4 Proportion of arable land in the study area (\%) in individual agroclimatic zones and subgroups in the nine periods listed in Fig. 1

\begin{tabular}{|c|c|c|c|c|c|c|c|c|c|c|}
\hline \multirow{2}{*}{$\begin{array}{l}\text { Agroclimatic } \\
\text { zone }\end{array}$} & \multirow[t]{2}{*}{ Subgroup } & \multicolumn{9}{|l|}{ Period } \\
\hline & & $1803-1825$ & $1826-1850$ & $1851-1875$ & 1876-1900 & $1901-1925$ & 1926-1950 & 1951-1975 & 1976-2000 & 1985-2008 \\
\hline \multirow[t]{2}{*}{ Grain maize } & 1 & 12.3 & 19.8 & 21.1 & 14.8 & 10.8 & 15.5 & 15.7 & 23.5 & 19.3 \\
\hline & 2 & 3.0 & 4.7 & 5.1 & 2.5 & 1.7 & 3.1 & 3.0 & 5.9 & 5.5 \\
\hline \multirow[t]{2}{*}{ Sugar beet } & 1 & 19.4 & 12.1 & 11.0 & 14.1 & 15.9 & 15.9 & 15.5 & 9.7 & 14.1 \\
\hline & 2 & 11.3 & 9.5 & 9.6 & 7.1 & 6.4 & 10.7 & 10.6 & 14.7 & 18.5 \\
\hline \multirow{2}{*}{$\begin{array}{l}\text { Cereal and } \\
\text { potato }\end{array}$} & 1 & 1.8 & 1.6 & 1.3 & 4.6 & 6.7 & 2.0 & 2.2 & 0.2 & 0.0 \\
\hline & 2 & 18.6 & 18.1 & 17.9 & 20.9 & 21.3 & 18.9 & 18.7 & 12.6 & 9.4 \\
\hline $\begin{array}{r}\text { Forage and } \\
\text { grassland }\end{array}$ & 2 & 0.5 & 1.2 & 0.8 & 2.9 & 4.0 & 0.8 & 1.2 & 0.3 & 0.1 \\
\hline
\end{tabular}

Subgroup 1 included the most fertile soils, which are primarily used for agricultural production; subgroup 2 included soils that are, in general, less fertile but that can be used for crop production, typically with some type of amelioration; in all cases, only areas with slopes less than $7^{\circ}$ were considered. In the case of the forage and grassland zone, subgroup 1 was not present in the study area 

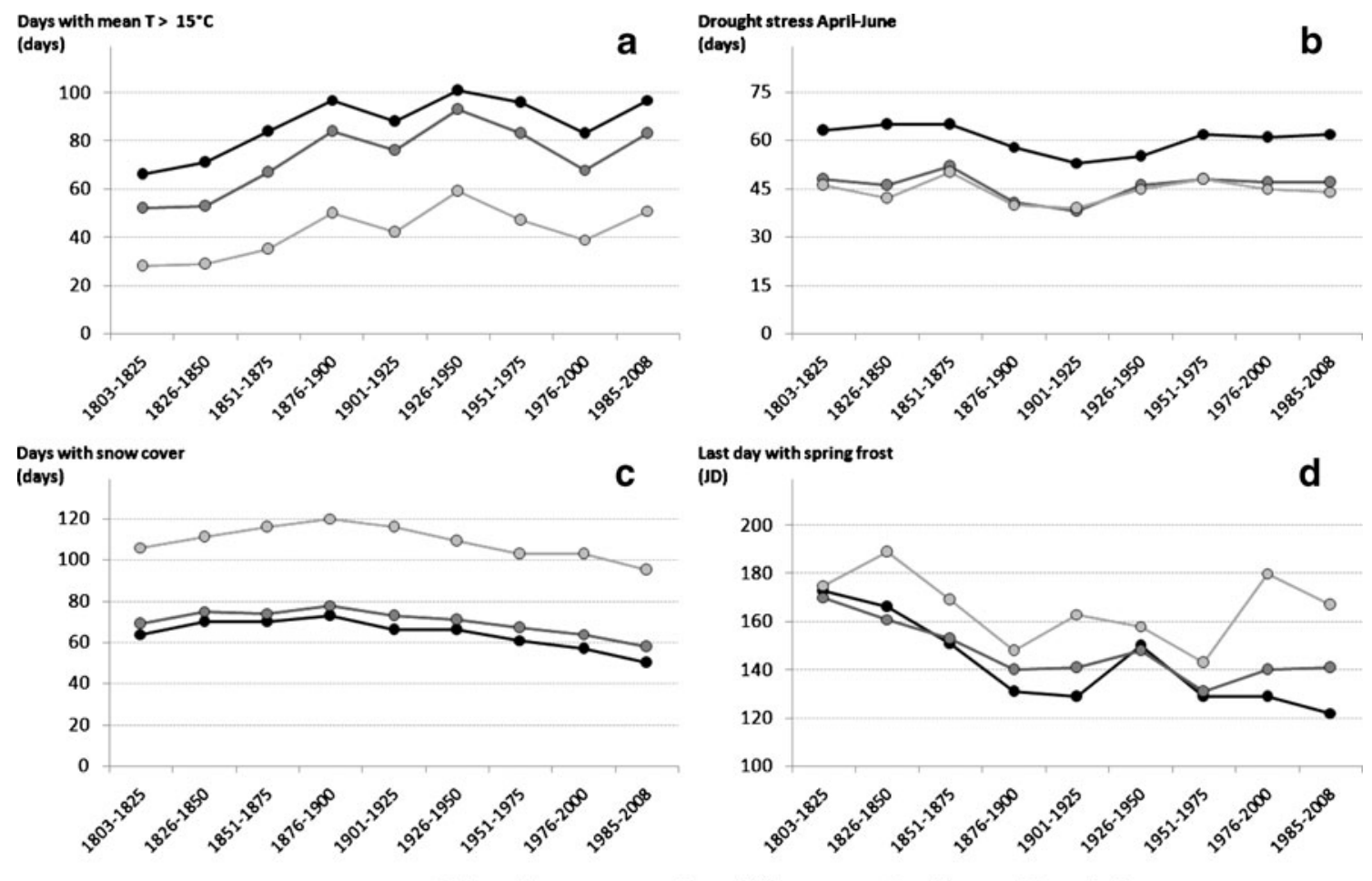

Last day with spring frost

(JD)

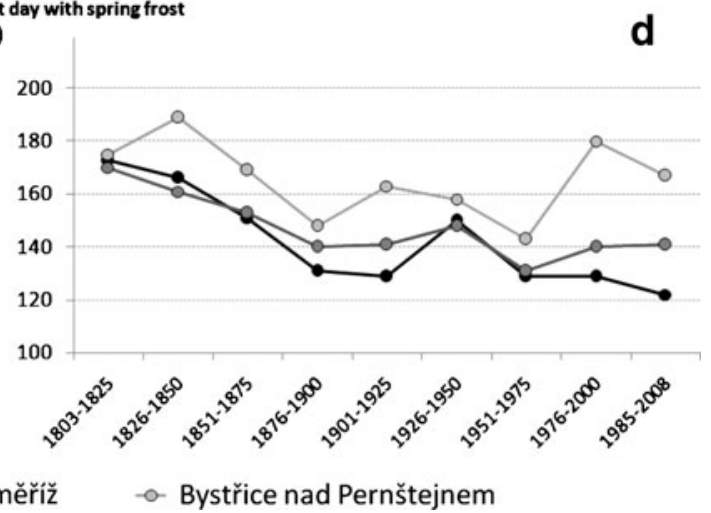

Fig. 2 Values of agroclimatic indicators for Schwechat, Kroměříž and Bystřice nad Pernštejnem: a mean duration of the vegetation summer; b number of days with water stress between April and June during dry

years, with 20-year return probability; c mean number of days with snow cover; and $\mathbf{d}$ the date of the last spring frost, with 20 -year return probability ( $J D$ Julian days)

For the 1975-2000 period, the agroclimatic zone with the highest productivity (sugar beet-growing zone on most fertile soils) represented $9.7 \%$ of the study area in Austria and the Czech Republic, while the grain maize-growing zone on fertile soils (Table 4) represented $23.5 \%$ of the area and tended to be less productive. The temporal dynamics of individual zones showing pronounced fluctuations are presented in Fig. 1. The total area of the grain maizegrowing zone was the greatest between 1826 and 1875 and after 1976. In the 1901-1925 period, the area of the maizegrowing and sugar beet-growing zones was reduced, and the area of the two remaining zones was the greatest. After
Fig. 3 Temporal stability of the given cadastre unit, expressed as the percentage of time between 1803 and 2008 in which the cadastre unit belonged to the same zone as in the 1975-2000 period. The areas without shading are areas in which the agroclimatic zone was stable for the entire 200-year period

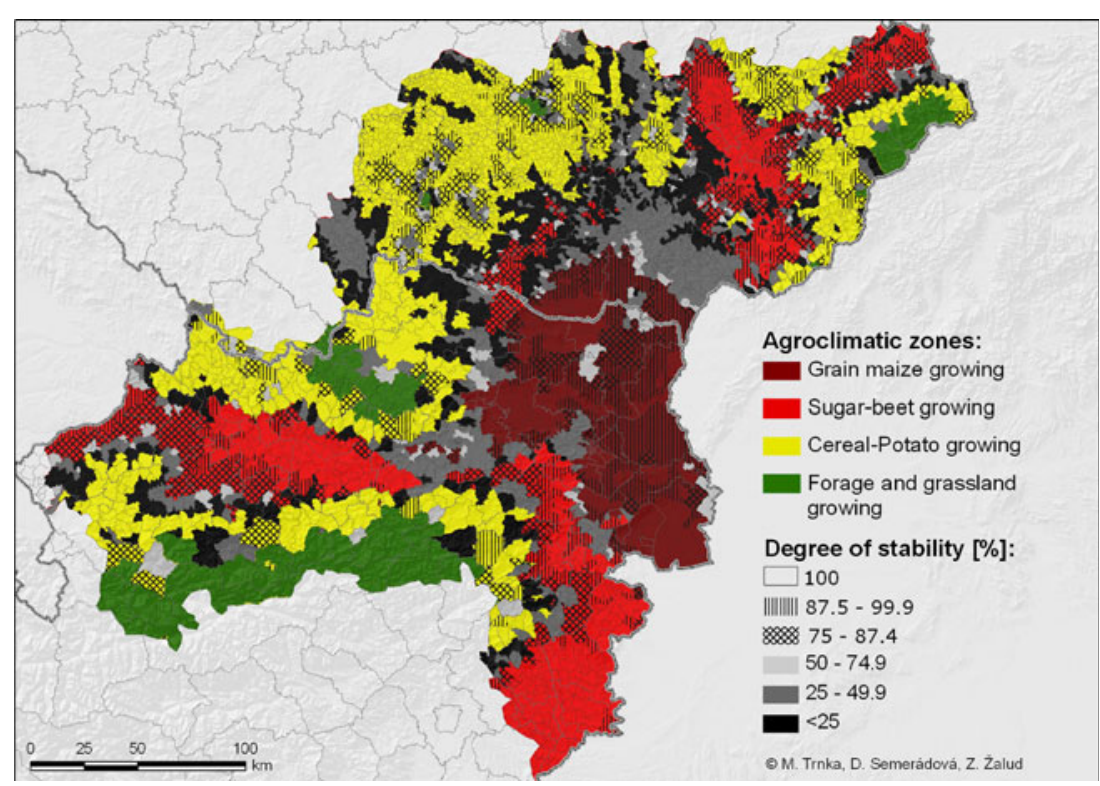


Fig. 4 The estimated extent of agroclimatic zones by 2050 , assuming high climate sensitivity and a $\mathrm{CO}_{2}$ concentration of $535.9 \mathrm{ppm}$, for three General Circulation Models: a HadCM, b ECHAM, and c NCAR. Compare to the changes estimated for the past 200 years (Fig. 1). A more detailed description of the

agroclimatic zone classification is presented in Tables 1 and 5
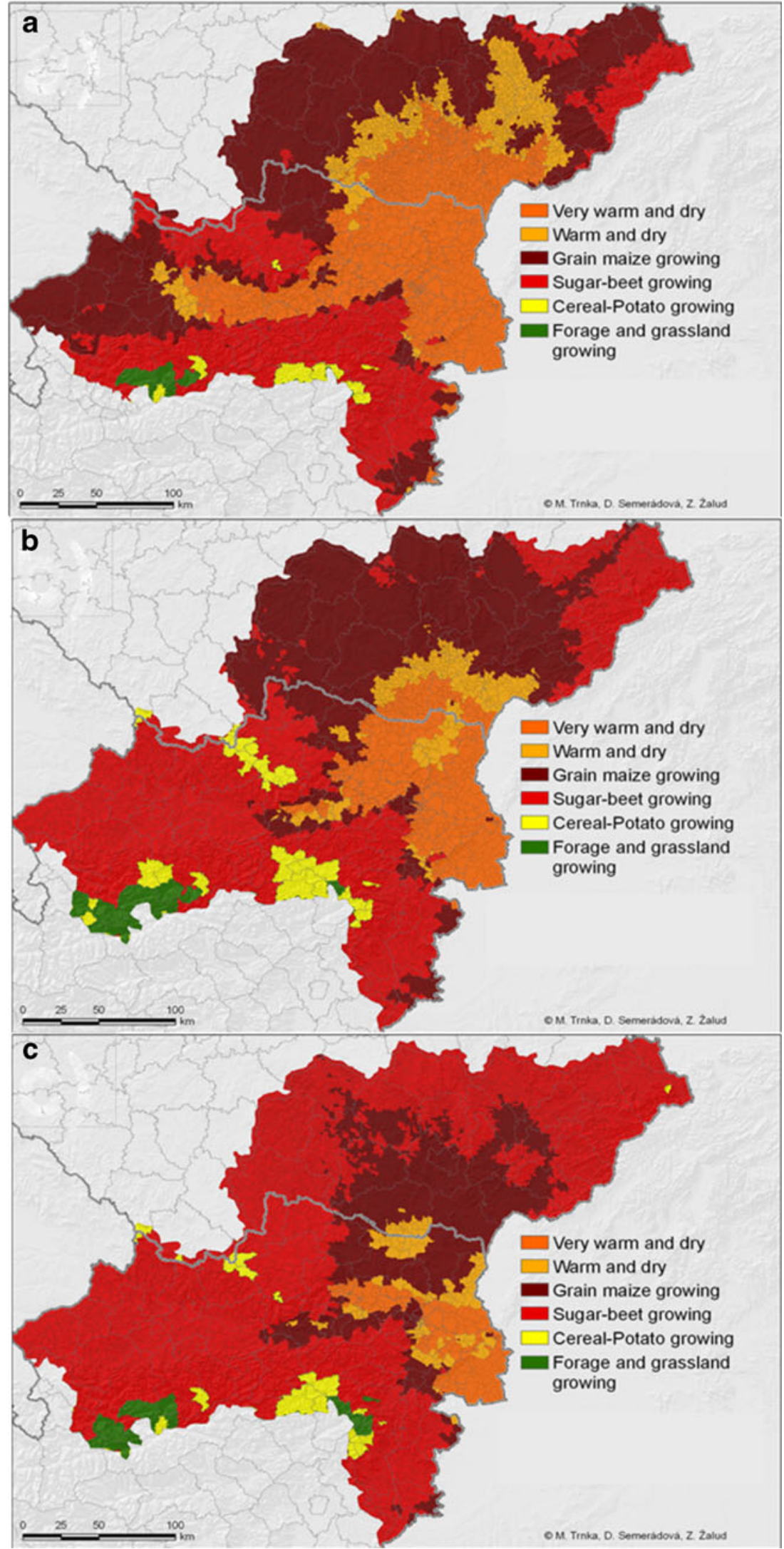
1925, the continuous expansion of grain maize-growing and, particularly, sugar beet-growing zones, with significantly reduced forage and grassland areas, was estimated (Fig. 1 and Table 2). The situation after 1975 (Fig. 1h and i) was qualitatively different from that of the nineteenth century (Fig. 1c) due to unprecedented intrusions of sugar beetgrowing zones into higher elevations, which reached $56.5 \%$ of the total area, and a northward expansion of the grain maizegrowing region. In the same period, the forage and grassland zone was reduced to approximately $1 \%$ of the study area.

The shifts of agroclimatic zones shown in Fig. 1 were supported by changes in other indicators (Fig. 2). There was a clear trend toward longer vegetation summers at low and high elevations and in the north and south areas of the region (Fig. 2a). For all 52 sites, there was no significant trend in days with drought stress during the peak of the growing season (April-June). The mean number of days with snow cover decreased by up to 30 days since the peak in the late nineteenth century (Fig. 2c), and this was consistent for all sites. The date of the last frost (with a 20-year return period) shifted significantly closer to the beginning of the season (Fig. 2d) for lowland sites, while this date was mostly unchanged at higher elevations.

Figure 3 summarizes shifts in individual agroclimatic zones and shows the most and least stable regions in terms of agroclimatic zoning. While the core grain maize-growing zone was found near the Neusiedler See area in Austria on the Czech-Austrian border, the most stable area of the sugar beetgrowing zone was found in the north of the study region around the Danube valley and in the southern tip of the region, which is one of the key breadbaskets of the Czech Republic. Although these regions were classified as stable, the agroclimatic conditions in the core regions changed, but the changes did not pass predefined thresholds. The area north of the Austrian border was, in general, the least stable region, as the conditions typical for a sugar beet-growing zone were frequently replaced by conditions for grain maize- or cereal- and potato-growing zones (Fig. 1). The forage and grassland zone showed the highest temporal instability, particularly in the Czech Republic. The most stable area was located in the Alps. However, cultivation in these areas was complicated by the complex terrain, which in many cases required special machinery. At the same time, the poor soil quality in these areas and the topographically complex terrain hampered the adaptation of alternative production systems to the currently dominant and permanent grassland-based dairy farming or forestry.

The combination of increased air temperature and changes in the total and annual cycle of precipitation predicted for the next decades (Table 3) will lead to significant shifts in the area and location of individual agroclimatic zones (Fig. 4). In all cases, the area of the cereal- and potato- and forage and grassland zones will be reduced greatly by 2050 and substituted by sugar beet- and grain maize-growing zones. Similar claims were made by Olesen et al. (2007, 2011), who analyzed the expansion of the area suitable for maize production in Central and Northern Europe under climate change projections. However, the most striking difference with the present study was the appearance of two completely new agroclimatic zones, provisionally named the "warm and dry zone" and the "very warm and dry zone." More detailed parameters are described in Table 5. Farmers currently located in the two most productive regions, the sugar beet-growing zone, where the climate is nearly optimal for rain-fed agriculture, and the grain maize-growing zone, would be the most severely impacted. Agricultural land within these zones is characterized by very fertile and deep soils and relatively flat terrain. The negative impact of the projected changes will likely be more severe in the Czech Republic because there are relatively limited possibilities for irrigation, overall water resources are likely to decrease (Dvořák et al. 1997; Kalvová et al. 2002) and larger average field sizes are an important factor for wind and water erosion during periods of drought. While the growing season in the warm

Table 5 Overview of thresholds used for "newly" emerging agroclimatic zones

\begin{tabular}{|c|c|c|c|c|c|c|c|c|}
\hline $\begin{array}{l}\text { Agroclimatic } \\
\text { zone }\end{array}$ & $\begin{array}{l}\mathrm{TS} 10 \\
\left({ }^{\circ} \mathrm{C}\right)^{\mathrm{a}}\end{array}$ & $\begin{array}{l}\mathrm{K}_{\mathrm{JJA}} \\
(\mathrm{mm})^{\mathrm{b}}\end{array}$ & $\begin{array}{l}\text { Annual mean } \\
\text { air temperature } \\
\left({ }^{\circ} \mathrm{C}\right)\end{array}$ & $\begin{array}{l}\text { Annual } \\
\text { precipitation } \\
\text { total }(\mathrm{mm})\end{array}$ & $\begin{array}{l}\text { Mean } \\
\text { altitude } \\
\text { (m a.s.1.) }\end{array}$ & $\begin{array}{l}\text { Prevailing soils } \\
\text { (under present } \\
\text { climate) }\end{array}$ & $\begin{array}{l}\text { Major crops } \\
\text { grown in the } \\
\text { zone }\end{array}$ & $\begin{array}{l}\text { Potential } \\
\text { productivity } \\
(\%)^{\mathrm{c}}\end{array}$ \\
\hline $\begin{array}{l}\text { Very warm and } \\
\text { dry zone }\end{array}$ & $>3400$ & $<-250$ & $>11.5^{\circ} \mathrm{C}$ & $\mathrm{NA}^{1}$ & NA & NA & NA & NA \\
\hline $\begin{array}{l}\text { Warm and } \\
\text { dry zone }\end{array}$ & $3100-3500$ & -180 to -250 & $10-11.5^{\circ} \mathrm{C}$ & $<600$ & $<140$ & $\begin{array}{l}\text { Solonetz, } \\
\text { chernozems }\end{array}$ & $\begin{array}{l}\text { Grain maize, } \\
\text { soybean, grape } \\
\text { wine, irrigated } \\
\text { agriculture }\end{array}$ & NA \\
\hline
\end{tabular}

$N A$ not available or not known

${ }^{\mathrm{a}} \mathrm{TS} 10\left({ }^{\circ} \mathrm{C}\right)$ : sum of temperatures in days with mean daily temperature above $10^{\circ} \mathrm{C}$

${ }^{\mathrm{b}} \mathrm{K}_{\mathrm{JJA}}$ : the water deficit during the period from June to August

"Conditions resembling the "warm and dry" zone could be identified in few cadastre units in low-lying regions of northeastern Austria during the analyzed period from 1995 to 2008 
and dry production regions is much longer, pervasive drought during the summer months will limit rain-fed farming outside of the June-August period.

\section{Conclusions}

This study showed that agroclimatic conditions have varied substantially across most of the study area and, most likely, across the entire Central European region over the past 200 years. Changes of climate factors since the second half of the twentieth century favored the expansion of the maize agroclimatic zone. The length of the vegetation summer increased over the past two centuries, and the mean number of days with snow cover dropped by up to 30 days since the peak in the late nineteenth century. The date of the last frost became significantly closer to the season beginning in lowland sites but remained unchanged at higher elevations.

When analyzing upcoming decades, the time scale of the predicted changes is important. Farmers in Central Europe have never been forced, in past seven generations, to deal with such changes in agroclimatic conditions. They present great challenges for appropriate and sustainable farming strategies, such as change of crops, crop rotation schemes, cultivation timing and practices, and the abandonment of some forms of agricultural production. Based on the dynamics of the studied changes, the concept of stable agroclimatic zones used in the study region should, in general, be changed to a more flexible and continuous adaptive system that could be updated on the scale of decades or shorter timeframes. Finally, the results from this study are based on three GCMs, a rather small subset of all GCMs available. Hypothetically, if climate change scenarios based on all available GCM simulations were used in this analysis, then the GCM uncertainties in the results would likely be larger than those based on the three GCMs used in this study; however, the main trends would be preserved.

The methodology presented in this article can be easily applied to any region with available input data and a combination of long-term datasets and projections of future development to provide insight into the challenges that agriculture could face in the near future.

Acknowledgements We gratefully acknowledge the support of the Grant Agency of the Czech Republic (Project no. 521/08/1682), project KONTAKT ME 10128 and Research Plan No. MSM6215648905, "Biological and technological aspects of sustainability of controlled ecosystems and their adaptability to climate change." Soil data were provided thanks to support of National Agency for Agricultural Research project number Q191C054.

\section{References}

Allen GA, Walter IA, Elliot RL, Howell TA (2005) ASCE standardized reference evapotranspiration equation. American Society of Civil Engineers, Reston

Auer I, Böhm R, Jurković A, Orlik A, Potzmann R, Schöner W, Ungersböck M, Brunetti M, Nanni T, Maugeri M, Briffa K, Jones P, Efthymiadis D, Mestre O, Moisselin J-M, Begert M, Brazdil R, Bochnicek O, Cegnar T, Gajić-Čapka M, Zaninović K, Majstorović Ž, Szalai S., Szentimrey T, Mercalli L (2005) A new instrumental precipitation dataset for the greater Alpine region for the period 1800-2002. Int J Climatol 25:139-166

BMLFW - Bundesministerium für Land- und Forstwirtschaft, Umwelt und Wasserwirtschaft (2007) Digitaler Hydrologischer Atlas von Österreich. Österreichischer Kunst und Kulturverlag, Wien

Brázdil R, Řezníčková L, Valášek H (2006) Early instrumental meteorological observations in the Czech Lands I: Ferdinand Knittelmayer, Brno, 1799-1812. Meteorol Čas 9:59-71

Brázdil R., Valášek H., Macková J. (2005) Meteorological observations in Brno in the first half of the 19th century. History of weather and hydrometeorological extremes (in Czech), Archiv města Brna, Brno.

Červený A (1871) Equipment and auditing of agricultural estates (in Czech). Matice rolnická v Praze, Prague

Dobrovolný P, Moberg A, Brázdil R, Pfister C, Glaser R, Wilson R, van Engelen A, Limanówka D, Kiss A, Halíčková M, Macková J, Riemann D, Luterbacher J, Böhm R (2010) Monthly and seasonal temperature reconstructions for Central Europe derived from documentary evidence and instrumental records since AD 1500. Clim Change 101:69-107. doi:10.1007/ s10584-010-9866-x

Dokládal J (1947) First assessment of dry areas in south Moravia (in Czech). Časové otázky zemědělské 74:37-46

Dvořák V, Hladný J, Kašpárek L (1997) Climate change hydrology and water resources impact and adaptation for selected river basins in the Czech Republic. Clim Change 36:93-106. doi:10.1023/A:1005384120954

Dubrovský M, Buchtele J, Žalud Z (2004) High-frequency and lowfrequency variability in stochastic daily weather generator and its effect on agricultural and hydrologic modelling. Clim Change 63:145-179. doi:10.1023/B:CLIM.0000018504.99914.60.

Farr TG, Rosen PA, Caro E, Crippen R, Duren R, Hensley S, Kobrick M, Paller M, Rodriguez E, Roth L, Seal D, Shaffer S, Shimada J, Umland J, Werner M, Oskin M, Burbank D, Alsdorf D (2007) The Shuttle Radar Topography Mission. Rev Geophys 45: RG2004. doi:10.1029/2007JD008451.

Fotheringham SA, Brunsdon C, Charlton M (2002) Geographically Weighted Regression: the Analysis of Spatially Varying Relationships. Wiley, Chichester

Harlfinger O, Knees G (1999) Klimahandbuch der Österreichischen Bodenschätzung. Mitteilung der Österreichischen Bodenkundlichen Gesellschaft 58:196

Hulme M, Wigley TML., Barrow EM, Raper SCB., Centella A, Smith S, Chipanshi AC (2000) Using a climate scenario generator for vulnerability and adaptation assessments: MAGICC and SCENGEN Version 2.4 Workbook. Climatic Research Unit, Norwich.

Kalvová J, Kašpárek L, Janouš D, Žalud Z, Kazmarová H (2002) (Eds.) Climate change induced impacts on water regime, agriculture, forestry and human health in the Czech Republic (in Czech). National Climatic Program of the Czech Republic, no. 32, Praha.

Klijn F, de Haes HAU (1994) A hierarchical approach to ecosystems and its implications for ecological land classification. Landscape Ecol 9:89-104. doi:10.1007/BF00124376. 
Kořistka K (1860) Die Markgrafschaft Mähren und das Herzogthum Schlesien. Wien, Olmütz

Kruijt B, Witte JPM, Jacobs CMJ, Kroon T (2008) Effects of rising atmospheric $\mathrm{CO}_{2}$ on evapotranspiration and soil moisture: $\mathrm{A}$ practical approach for the Netherlands. J Hydrol 349:257-267. doi:10.1016/j.jhydrol.2007.10.052

Murer E, Wagenhofer J, Aigner F, Pfeffer M (2004) Die nutzbare Feldkapazität der mineralischen Böden der landwirtschaftlichen Nutzfläche Österreichs. Schriftenreihe BAW 20:72-78

Němec J (2001) Assessment and Evaluation of Farm Land in the Czech Republic (in Czech). Výzkumný ústav zemědělské ekonomiky, Prague

Olesen J, Fronzek S, Heidmann T, Hickler T, Holt T, Minguez MI, Morales P, Palutikov J, Quemada M, Ruiz-Ramos M, Rubæk G, Sau F, Smith B, Sykes M (2007) Uncertainties in projected impacts of climate change on European agriculture and ecosystems based on scenarios from regional climate models. Clim Change 81:123-143. doi:10.1007/s10584-006-9214-3

Olesen JE, Trnka M, Kersebaum KC, Skejvåg AO, Seguin B, PeltonenSainio P, Rossi F, Kozyra J, Micale F (2011) Impacts and adaptation of European crop production systems to climate change. Eur J Agron 34(2):96-112. doi:10.1016/j.eja.2010.11.003

Perarnaud V, Seguin B, Malezieux E, Deque M, Loustau D (2005) Agrometeorological research and applications needed to prepare agriculture and forestry to 21 st century climate change. Clim Change 70:319-340. doi:10.1007/s10584-005-5953-9

Petr J (ed) (1991) Weather and Yield. Elsevier, Amsterdam

Porter JR, Gawith M (1999) Temperatures and the growth and development of wheat: a review. European J Agron 10:23-36. doi:10.1016/S1161-0301(98)00047-1

Santer BD, Wigley TML, Schlesinger ME, Mitchell JFB (1990) Developing climate scenarios from equilibrium GCM results, Report No. 47. Max Planck Institut für Meteorologie, Hamburg

Štěpánek P, Zahradníček P, Skalák P (2009) Data quality control and homogenization of air temperature and precipitation series in the area of the Czech Republic in the period 1961-2007. Adv Sci Res 3:23-26

Tomášek M (2000) Soils of the Czech Republic (in Czech). Česká geologická služba, Prague

Trnka M, Dubrovský M, Žalud Z (2004) Climate change impacts and adaptation strategies in spring barley production in the Czech Republic. Clim Change 64:227-255. doi:10.1023/B: CLIM.0000024675.39030.96.

Trnka M, Kocmánková E, Balek J, Eitzinger J, Ruget F, Formayer H, Hlavinka P, Schaumberger A, Horáková V, Možný M (2010) Simple snow cover model for agrometeorological applications. Agr Forest Meteorol 150:1115-1127. doi:10.1016/j.agrformet.2010.04.012 